\title{
Modelling and calculation of a small-size evaporation cooling apparatus for industrial recirculated water with a heat-and-mass exchange packing based on wastes from metal- working machinery
}

\author{
Nikolay Merentsov ${ }^{1, *}$, Alexander Golovanchikov ${ }^{1}$, Vitaliy Lebedev², and Alexander \\ Gendler $^{1}$ \\ ${ }^{1}$ Volgograd State Technical University, 400005 Volgograd, Russia \\ ${ }^{2}$ Branch of LUKOIL-Engineering VolgogradNIPImorneft, 400078 Volgograd, Russia
}

\begin{abstract}
The article presents the results of the experiments on fluid and gas dynamics through a layer of packing material S-Aisi304 ${ }_{\varepsilon-0,95}(\varepsilon=0,95$, $\sigma=160 \mathrm{~m}^{2} / \mathrm{m}^{3}$ ) suggested for use as packing blocks in small-size evaporation cooling apparatuses for industrial recirculated water. Experimentally confirmed effects are covered that prove the performance efficiency of wastes from metal-working machinery as packing materials for contact evaporation blocks. Results of mathematical modelling and engineering calculation of the main process parameters and dimensions for a small-size evaporation cooling apparatus for industrial recirculated water with use of contact blocks filled with the studied packing material are provided.
\end{abstract}

\section{Introduction}

Low-grade heat transfer from the recirculated water by means of its cooling with atmospheric air is widely used in different technical equipment and process systems. Such recirculated water cooling method is widely used in many industries: chemical, petrochemical, oil-and-gas, nuclear, metallurgical, construction, food processing and many other related fields. Small-size evaporation coolers are widely used in local systems of recycling water supply. Thus, designing of structures for evaporation cooling apparatuses and packing materials (packing elements), which have small dimensions and energy consumption and at the same time a relatively high capacity, is a challenging engineering task. The main structural element in evaporation cooling apparatus ensuring the required efficiency of recirculated water cooling is the heat-and-mass exchange packing [1-23].

Operation efficiency of evaporation cooling apparatuses mainly depends on the operation efficiency of their contact packings [24-50]. Papers [4, 9, 10, 51] demonstrate that spraying units having fibre structure and having high values of porosity and specific surface are very promising in this sphere. An important feature of such fibre structure is that it is

\footnotetext{
* Corresponding author: steeple@mail.ru
} 
simple and easily manufactured [51-53]. We regard use of fibre structures, i. e. wastes from metal-working machinery produced in the course of processing of stainless alloyed steels [51-56] (that are resistant to weather and aggressive actions), or polymer threads of different thickness and section, i. e. wastes of synthetic fibre manufacturing plants [51], as one of the most promising energy- and resource saving trends for designing and manufacturing of evaporation cooling apparatuses and packing contact blocks. Packing materials in the form of packaged blocks of wastes from metal-working machinery (metal shavings) feature a range of important structural and surface properties [51-56], i. e. they have a curly structure with microroughness and chips on the surface. All these structural and surface features result in swirling and purling of the air stream moving through the packing element layer, and liquid in its turn moves in droplet-film flow by the surfaces of the packing elements. Such structural and surface features intensify heat-and-mass exchange processes occurring between recirculated water and upward air stream and meet the requirements for evaporation cooling of industrial recirculated water with regard to the organization of liquid and air (gas) flows with respect to each other. Such materials can be easily used to form cubic or rectangular blocks (cylinder-shaped form of packing blocks is even easier to be created [51-56]) with dimensions approximately 200-600 mm that allows visual control of their internal structure. If necessary, the block can have the required stiffness if it is placed in a wire cage. Such blocks can form a packing layer of required size and configuration. Both droplet- film and developed droplet flow mode can be implemented in packing blocks (evaporation cooling blocks) depending on the equivalent diameter value that can range from 5 to $10-12 \mathrm{~mm}$ and on air flow velocity. Packing blocks with high equivalent diameter values have high permeability, low resistance to flow and can be larger in height.

\section{Methods and materials}

The study considers heat-and-mass exchange process of recirculated water cooling in smallsize apparatuses, where packing blocks (evaporation cooling blocks) are created of wastes from metal-working machinery, i. e. from metal shavings formed during machine processing of stainless allowed steels that are resistant to weather and aggressive actions, and their evaporation packing blocks are working with the development and maintenance of intensive liquid droplet flows. The objective of the study is to prove the application perspectiveness of heat-and-mass exchange blocks with wastes from metal-working machinery and the elaborated method of engineering calculation aimed at determination of the main process parameters and dimensions of small-size evaporation cooling apparatuses for industrial recirculated water (dimensions of evaporation cooling packing block for the pre-set operating conditions of the apparatus with regards to the flow rates of cooled water and air, temperatures of air and water flows in the extreme sections of the packing blocks with known initial parameters of air flow humidity) ensuring developed droplet-film or droplet liquid flows through the evaporation block packing layer. The calculation is based on the determination of phase contact surfaces ensuring the required heat takeoff by means of heat exchange and required moisture exchange (mass exchange) with further agreement of the values of these surfaces. The obtained experimental values of heat-and-mass exchange factors are used in the calculation for the studied packing block and liquid droplet flow retained by the packing.

Figure 1 presents the photo of the contact block and experimental plant. Let us consider the obtained experimental data on resistance to flows of the dry and irrigated evaporation cooling packing block based on the wastes from metal-working machines (Packing material S-Aisi304 ${ }_{\varepsilon-0,95}\left(\varepsilon=0,95 \mathrm{~m}^{3} / \mathrm{m}^{3}, \sigma=160 \mathrm{~m}^{2} / \mathrm{m}^{3}\right)$ (ref. to Figure 2). 


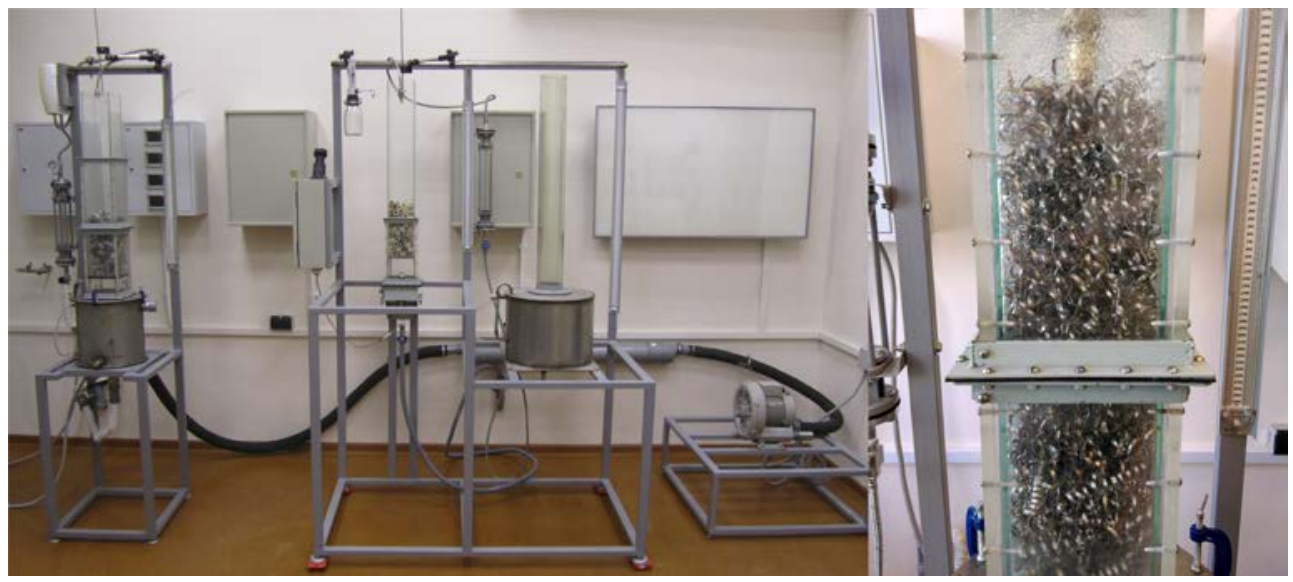

Fig. 1. Photo of the experimental plant for studying fluid and gas dynamics and heat-and-mass exchange processes in packing contact devices [57] and photo of the contact block (Packing material S-Aisi304 ${ }_{\varepsilon-0,95} \varepsilon=0,95, \sigma=160 \mathrm{~m}^{2} / \mathrm{m}^{3}$ ).

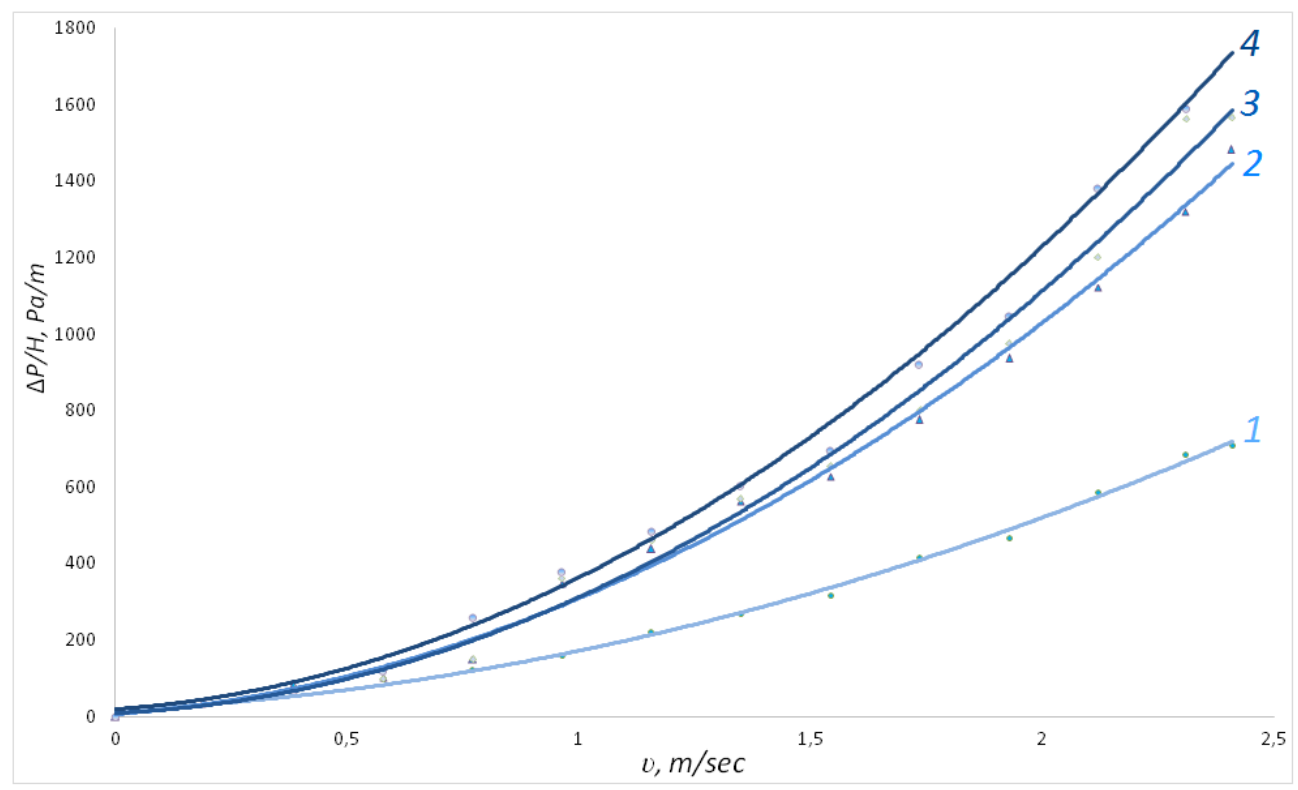

Fig. 2. Experimental data on the study of hydrodynamics through a layer of packed material $S$ Aisi304 ${ }_{\varepsilon-0,95}\left(\varepsilon=0,95, \sigma=160 \mathrm{~m}^{2} / \mathrm{m}^{3}\right)$ : single-phase filtration curve 1 and filtration curves at different irrigation densities $2-q_{w}=1,6 \mathrm{kgW} / \mathrm{m}^{2} \cdot \mathrm{s} ; 3-q_{w}=1,9 \mathrm{kgW} / \mathrm{m}^{2} \cdot \mathrm{s} ; 4-q_{w}=2,4 \mathrm{kgW} / \mathrm{m}^{2} \cdot \mathrm{s}$.

The analysis of the provided experimental data (ref. to Table 1) and comparison with the performance of the packing contact devices that are widely used in the industry [58-59] make it evident that the studied packing material ensures a high permeability of the packing block (Low values of specific flow resistance) and even organization of the liquid flow mode through the layer of the packing materials with different density of irrigation and besides ensures a relatively high liquid retaining capacity [51, 52, 54]. A rather high efficiency of the studied material with regard to heat-and-mass exchange performance has been experimentally proved (ref. to Table 1). All properties above prove the industrial applicability of the created packing materials based on the wastes from metal-working 
machines used as evaporation blocks in heat-and-mass exchange evaporation heating apparatuses of recirculated water.

The most important experimentally confirmed property is the capacity of the studied packing material S-Aisi $304_{\varepsilon-0,95}\left(\varepsilon=0,95, \sigma=160 \mathrm{~m}^{2} / \mathrm{m}^{3}\right)$ to develop an intensive droplet flow mode by the whole height of the packing block. (Droplet-film flow mode with prevailing droplets) Thus, the method for engineering calculation of heat-and-mass exchange packing blocks in intensive droplet flow modes [51, 52, 60] that is shown in the block diagram in Figure 4 can be applied for calculation of an industrial evaporation cooling apparatus. The results of calculation of the main process parameters and dimensions of the small-size industrial evaporation cooling apparatus are provided in Table 1. Scheme of the modelled small-size heat-and-mass exchange evaporation cooling apparatus for industrial recirculated water with the studied packing modules represented by formed blocks of metal shavings $S$ Aisi304 $4_{\varepsilon-0,95}\left(\varepsilon=0,95, \sigma=160 \mathrm{~m}^{2} / \mathrm{m}^{3}\right)$ is provided in Figure 3 .
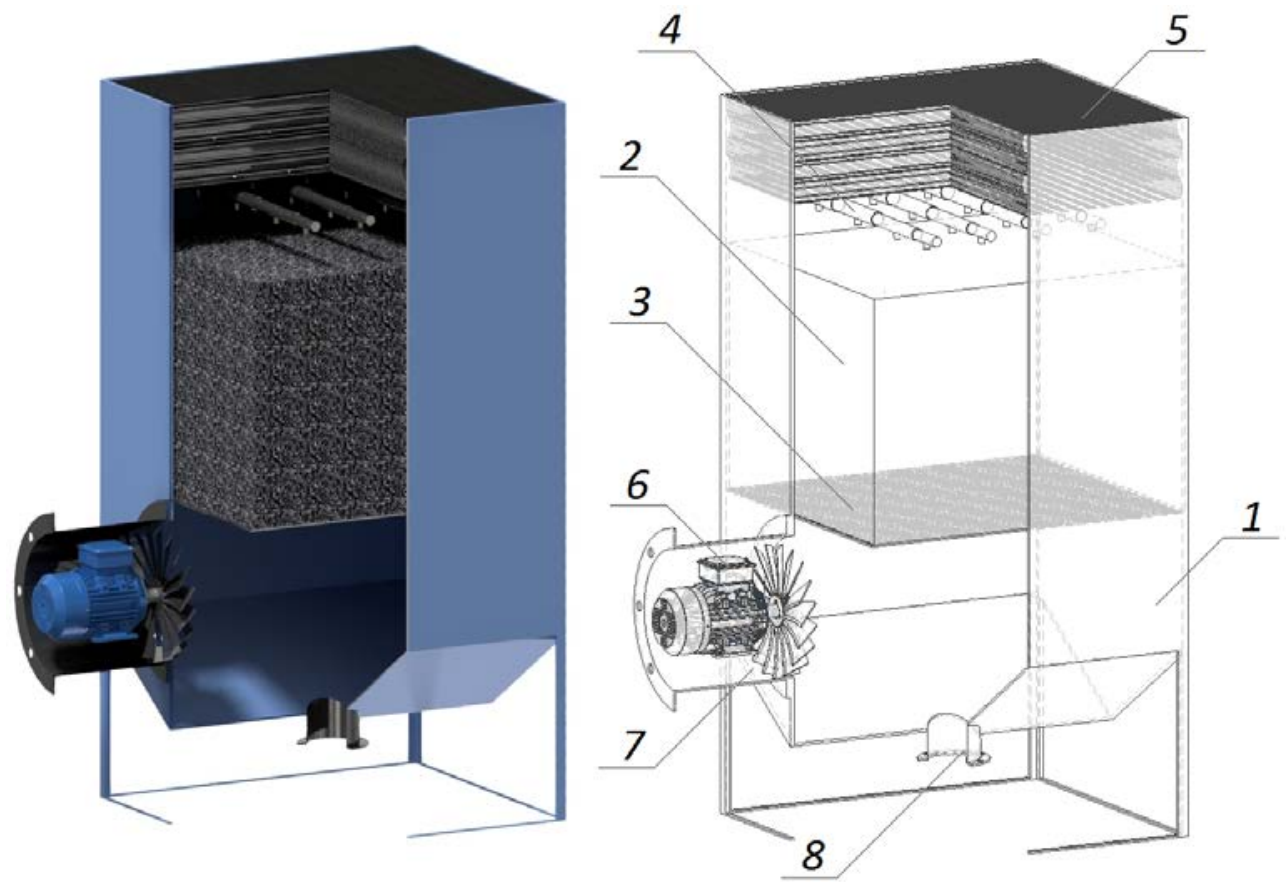

Fig. 3. Scheme of the small-size heat-and-mass exchange evaporation cooling apparatus for industrial recirculated water with the studied packing modules represented by blocks of formed metal shavings S-Aisi $304_{\varepsilon-0,95}\left(\varepsilon=0,95, \sigma=160 \mathrm{~m}^{2} / \mathrm{m}^{3}\right): 1$ - apparatus body, 2 - heat-and-mass exchange packing block evaporation cooling, 3 - support grid of the packing block, 4 - irrigation system, 5 - drop eliminators, 6 - blower, 7 - blower casing, 8 - drain pipe of the water collector. 


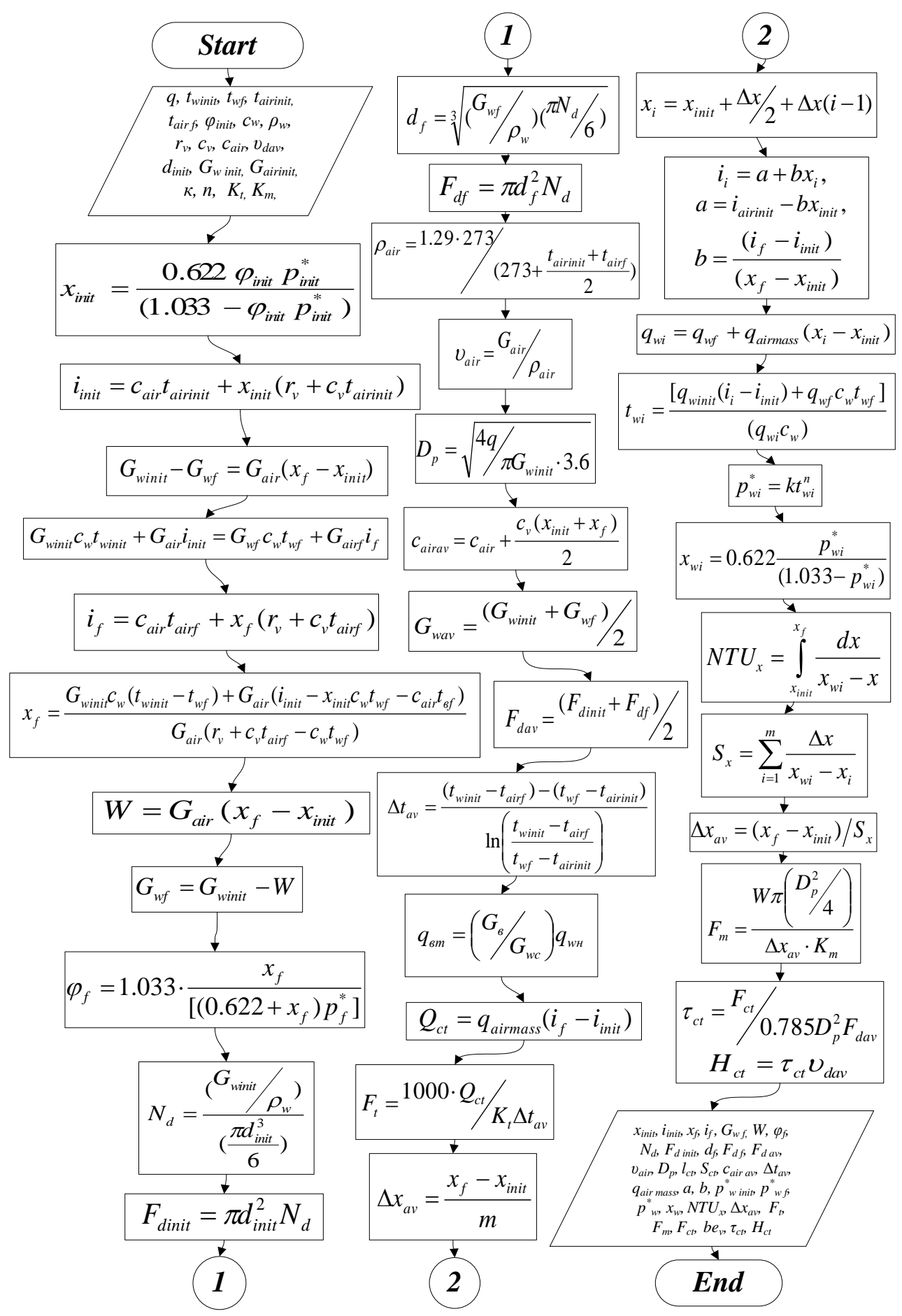

Fig. 4. Algorithm for calculation of process parameters and dimensions of the small-size evaporation cooling apparatus with heat and mass exchange packing ensuring an intensive dripping flow mode. 
Table 1. Initial, reference and calculation parameters of the designed small-size evaporation cooling apparatus with compressed metal shavings package used as packing material S-Aisi 304

\begin{tabular}{|c|c|c|c|c|}
\hline № & Parameter & Units & Symbol & Value \\
\hline 1 & 2 & 3 & 4 & 5 \\
\hline \multicolumn{5}{|c|}{ Initial data } \\
\hline 1 & Cooled water throughput & $m^{3} / h$ & $q$ & 15 \\
\hline 2 & Initial water temperature & ${ }^{\circ} \mathrm{C}$ & $\overline{t_{\text {winit }}}$ & 45 \\
\hline 3 & Final water temperature & ${ }^{\circ} \mathrm{C}$ & $t_{w f}$ & 25 \\
\hline 4 & Initial air temperature & ${ }^{\circ} \mathrm{C}$ & $t_{\text {airinit }}$ & 20 \\
\hline 5 & Final air temperature & ${ }^{\circ} \mathrm{C}$ & $t_{\text {airf }}$ & 32 \\
\hline 6 & Relative air humidity at the inlet & - & $\varphi_{\text {init }}$ & 0,70 \\
\hline \multicolumn{5}{|c|}{ Reference data } \\
\hline 1 & Average specific heat of water & $\mathrm{kJ} / \mathrm{kg} \mathrm{K}$ & $c_{w}$ & 4,18 \\
\hline 2 & Average water density & $\mathrm{kg} / \mathrm{m}^{3}$ & $\rho_{w}$ & 992 \\
\hline 3 & Specific evaporation heat at $0^{\circ} \mathrm{C}$ & $\mathrm{kJ} / \mathrm{kg}$ & $r_{v}$ & 2493 \\
\hline 4 & Specific heat of vapour & $\mathrm{kJ} / \mathrm{kg} \mathrm{K}$ & $c_{v}$ & 1,97 \\
\hline 5 & Specific heat of dry air & $\mathrm{kJ} / \mathrm{kg} \mathrm{K}$ & Cair & 1,01 \\
\hline 6 & Saturation vapour pressure at initial air temperature & atm & $p_{\text {init }}^{*}$ & 0,0233 \\
\hline 7 & Saturation vapour pressure at final air temperature & atm & $p_{f}^{*}$ & 0,0475 \\
\hline 8 & Average diameter of drops & $m$ & $d_{\text {init }}$ & $4 \cdot 10^{-3}$ \\
\hline 9 & Average water throughput & $\mathrm{kgW} / \mathrm{m}^{2} \cdot \mathrm{s}$ & $G_{\text {winit }}$ & 1,8 \\
\hline 10 & Average air throughput & $\mathrm{kgAIR} / \mathrm{m}^{2} \cdot \mathrm{s}$ & $G_{\text {air init }}$ & 2,3 \\
\hline 11 & $\begin{array}{l}\text { Coefficients of approximating exponential equation } \\
\text { in the dependence between water saturated vapour } \\
\text { pressure and temperature } p_{w}{ }^{*}=p^{*}\left(t_{w}\right)\end{array}$ & - & $\begin{array}{l}k \\
n\end{array}$ & $\begin{array}{c}3,5 \cdot 10^{-5} \\
2,086\end{array}$ \\
\hline 12 & $\begin{array}{l}\text { Average speed of drops } d_{\text {init }} \text { (obtained } \\
\text { experimentally using the laboratory plant with } \\
\text { heat-and-mass exchange packing S-Aisi304 }{ }_{\varepsilon-0,95} \\
\left(\varepsilon=0,95, \sigma=160 \mathrm{~m}^{2} / \mathrm{m}^{3}\right) \text { ) }\end{array}$ & $\mathrm{m} / \mathrm{s}$ & $v_{d a v}$ & 0,05 \\
\hline 13 & Heat transfer coefficient (experimentally obtained) & $W / m^{2} \cdot K$ & $K_{t}$ & 185 \\
\hline 14 & Mass transfer coefficient (experimentally obtained) & $\begin{array}{c}\mathrm{kgW} / \mathrm{m}^{2} \cdot \mathrm{s} \cdot \\
(\mathrm{kgW} / \mathrm{kgAIR})\end{array}$ & $K_{m}$ & 0,054 \\
\hline \multicolumn{5}{|c|}{ Design values of classifying generalized relation $\lambda=f\left(R e_{m}\right)$ (intermediate parameters) [58-59] } \\
\hline 1 & Modified Reynold’s number & - & $\operatorname{Re}_{m}$ & $\begin{array}{l}1,254 \\
1,568 \\
1,882 \\
2,196 \\
2,509 \\
2,823 \\
3,137 \\
3,450 \\
3,757 \\
3,921\end{array}$ \\
\hline 2 & Fluid resistance coefficient & - & $\lambda$ & $\begin{array}{l}3,594 \\
3,275 \\
3,062 \\
2,910 \\
2,796 \\
2,708 \\
2,637 \\
2,579 \\
2,532 \\
2,509\end{array}$ \\
\hline
\end{tabular}




\begin{tabular}{|c|c|c|c|c|}
\hline \multicolumn{5}{|c|}{ Calculated parameters } \\
\hline 1 & Initial moisture content in air & $\mathrm{kgW} / \mathrm{kgAIR}$ & $X_{\text {init }}$ & 0,0101 \\
\hline 2 & Initial enthalpy of air & $\mathrm{kJ} / \mathrm{kgAIR}$ & $i_{\text {init }}$ & 45,46 \\
\hline 3 & Final moisture content in air & $\mathrm{kgW} / \mathrm{kgAIR}$ & $x_{f}$ & $3,16 \cdot 10^{-2}$ \\
\hline 4 & Final enthalpy of air & $\mathrm{kJ} / \mathrm{kgAIR}$ & $i_{f}$ & 113,15 \\
\hline 5 & $\begin{array}{l}\text { Specific water throughput at the outlet of the } \\
\text { evaporation cooling apparatus }\end{array}$ & $\mathrm{kgW} / \mathrm{m}^{2} \cdot \mathrm{s}$ & $G_{w f}$ & 1,75 \\
\hline 6 & Specific quantity of water evaporating into the air & $\mathrm{kgW} / \mathrm{m}^{2} \cdot \mathrm{s}$ & $W$ & $4,978 \cdot 10^{-2}$ \\
\hline 7 & Relative humidity of air at the outlet & - & $\varphi_{f}$ & 1 \\
\hline 8 & Density of drop flow & $p c s / m^{2} \cdot s$ & $N_{d}$ & 54175 \\
\hline 9 & Initial specific surface of the drop flow & $\mathrm{m}^{2} / \mathrm{m}^{2} \cdot \mathrm{s}$ & $F_{d \text { init }}$ & 2,721 \\
\hline 10 & Final diameter of drops & $m$ & $d_{f}$ & $3,964 \cdot 10^{-3}$ \\
\hline 11 & Final specific surface of the drop flow & $\mathrm{m}^{2} / \mathrm{m}^{2} \cdot \mathrm{s}$ & $F_{d f}$ & 2,674 \\
\hline 12 & Average surface of the drop flow & $\mathrm{m}^{2} / \mathrm{m}^{2} \cdot \mathrm{s}$ & $F_{d a v}$ & 2,698 \\
\hline 13 & Speed of air & $\mathrm{m} / \mathrm{s}$ & vair & 1,95 \\
\hline 14 & $\begin{array}{l}\text { Diameter of the small-size evaporation cooling } \\
\text { apparatus } \\
\text { Width of the plane (if rectangular) }\end{array}$ & $\begin{array}{l}m \\
m\end{array}$ & $\begin{array}{l}D_{p} \\
l_{c t}\end{array}$ & $\begin{array}{l}1,72 \\
1,52\end{array}$ \\
\hline 15 & $\begin{array}{l}\text { Cross-sectional area of the small-size evaporation } \\
\text { cooling apparatus }\end{array}$ & $m^{2}$ & $S_{c t}$ & 2,322 \\
\hline 16 & Average specific heat of humid air & $\mathrm{kJ} / \mathrm{kg} \mathrm{K}$ & $c_{\text {air } a v}$ & 1,05 \\
\hline 17 & Average driving force of the heat exchange process & ${ }^{\circ} \mathrm{C}$ & $\Delta t_{a v}$ & 8,372 \\
\hline 18 & Mass air flow rate & $\mathrm{kgAIR} / \mathrm{s}$ & $q_{\text {air mass }}$ & 1,916 \\
\hline 19 & $\begin{array}{l}\text { Coefficients of the tie line } i=i(x) \text { in linear } \\
\text { dependence between enthalpy and moisture content } \\
\text { represented as } i=a+b x\end{array}$ & $\begin{array}{c}k J / k g W \\
k J / k g A I R\end{array}$ & $\begin{array}{l}a \\
b\end{array}$ & $\begin{array}{c}14,26 \\
3126,81\end{array}$ \\
\hline 20 & $\begin{array}{l}\text { Partial pressure of water vapours in air for } \\
t_{w f}=25^{\circ} \mathrm{C}(\varphi=1)\end{array}$ & atm & $p^{*}{ }_{\text {winit }}$ & 0,0233 \\
\hline 21 & $\begin{array}{l}\text { Partial pressure of water vapours in air for } \\
t_{\text {w init }}=45^{\circ} \mathrm{C}(\varphi=1)\end{array}$ & atm & $p^{*}{ }_{w f}$ & 0,0475 \\
\hline 22 & $\begin{array}{l}\text { Partial pressure of water vapours in air for current } \\
t_{w} \text { value }\end{array}$ & atm & $p^{*}{ }_{w}$ & $\begin{array}{l}\text { ref. to the } \\
\text { table } 2\end{array}$ \\
\hline 23 & $\begin{array}{l}\text { Moisture content in air nearby the drop surface for } \\
\text { current } t_{w} \text { value }\end{array}$ & $\mathrm{kgW/kgAIR}$ & $x_{w}$ & $\begin{array}{l}\text { ref. to the } \\
\text { table } 2\end{array}$ \\
\hline 24 & $\begin{array}{l}\text { Number of transfer units by moisture content of } \\
\text { vapours in air }\end{array}$ & - & $N T U_{x}$ & 1,463 \\
\hline 25 & $\begin{array}{l}\text { Average driving force of mass exchange process of } \\
\text { water evaporation into the air }\end{array}$ & $\mathrm{kgW} / \mathrm{kgAIR}$ & $\Delta x_{a v}$ & $1,479 \cdot 10^{-2}$ \\
\hline 26 & $\begin{array}{l}\text { Calculated surface of drops from heat transfer } \\
\text { condition }\end{array}$ & $m^{2}$ & $F_{t}$ & 837,59 \\
\hline 27 & $\begin{array}{l}\text { Calculated surface of drops from mass transfer } \\
\text { condition }\end{array}$ & $m^{2}$ & $F_{m}$ & 144,25 \\
\hline 28 & $\begin{array}{l}\text { Required calculated surface ensuring the processes } \\
\text { of heat- and mass transfer }\end{array}$ & $m^{2}$ & $F_{c t}$ & 837,59 \\
\hline 29 & $\begin{array}{l}\text { Volumetric coefficient (theoretical) as per the } \\
\text { Vaganov formula }\end{array}$ & - & $b e_{v}$ & 7,345 \\
\hline 30 & $\begin{array}{l}\text { Time of drops presence in the small-size } \\
\text { evaporation cooling apparatus required to maintain } \\
\text { the drop calculated surface }\end{array}$ & $S$ & $\tau_{c t}$ & 33,61 \\
\hline 31 & $\begin{array}{l}\text { Height of the small-size evaporation cooling } \\
\text { apparatus }\end{array}$ & $m$ & $H_{c t}$ & 1,68 \\
\hline
\end{tabular}


Table 2. Main calculated parameter of the small-size evaporation cooling apparatus related to the moisture content in air (required to determine the number of transfer units, intermediate parameters)

\begin{tabular}{|c|c|c|c|c|c|c|}
\hline \multirow[b]{2}{*}{ № } & \multirow{2}{*}{ Parameter } & \multicolumn{5}{|c|}{ Value } \\
\hline & & 1 & 2 & 3 & 4 & 5 \\
\hline 1 & Moisture content in air $x, \mathrm{kgW} / \mathrm{kgAIR} \cdot 10^{2}$ & 1,21 & 1,64 & 2,08 & 2,51 & 2,94 \\
\hline 2 & $\begin{array}{l}\text { Moisture content in air nearby the drop surface } \\
X_{w}, \mathrm{kgW} / \mathrm{kgAIR} \cdot 10^{2}\end{array}$ & 2,11 & 2,84 & 3,69 & 4,68 & 5,80 \\
\hline 3 & Enthalpy of air $i_{\text {air }}, k J / k g A I R$ & 52,23 & 65,77 & 79,31 & 92,85 & 106,4 \\
\hline 4 & Relative air humidity & 0,77 & 0,88 & 0,96 & 1 & 1 \\
\hline 5 & Air flow rate (dry) $Q_{\text {air }}, \mathrm{kgAIR} / \mathrm{s}$ & 1,916 & 1,916 & 1,916 & 1,916 & 1,916 \\
\hline 6 & Water flow rate $Q_{w}, \mathrm{kgW} / \mathrm{s}$ & 4,17 & 4,143 & 4,116 & 4,09 & 4,06 \\
\hline 7 & $\begin{array}{l}\text { Partial pressure of water vapours in air } p_{\text {air }} \text {, } \\
\text { atm } \cdot 10^{2}\end{array}$ & 1,97 & 2,66 & 3,34 & 4,01 & 4,67 \\
\hline 8 & $\begin{array}{l}\text { Pressure of water vapour nearby the drops } \\
\text { surface } p_{w}, a t m \cdot 10^{2}\end{array}$ & 8,81 & 7,23 & 5,79 & 4,51 & 3,39 \\
\hline 9 & Air temperature $t_{\text {air }},{ }^{\circ} \mathrm{C}$ & 21,24 & 23,70 & 26,12 & 28,50 & 30,84 \\
\hline 10 & Temperature of water drops $t_{w},{ }^{\circ} \mathrm{C}$ & 42,69 & 38,83 & 34,93 & 30,99 & 27,01 \\
\hline
\end{tabular}

\section{Conclusions}

The conducted experiments and mathematical modelling of the process demonstrated the advantages and perspectiveness of the use of wastes from metal-working machines as packing materials for the evaporation blocks in small-size evaporation cooling heat-andmass exchange apparatuses for industrial recirculated water. Especially when high-quality from the point of view of resistance to weather and aggressive actions wastes are available like the packing material studied herein S-Aisi304 $\varepsilon_{-0,95}\left(\varepsilon=0,95, \sigma=160 \mathrm{~m}^{2} / \mathrm{m}^{3}\right)$.

It is noteworthy that the experiments proved special properties of this packing material, i.e. high permeability of the packing layer and development of an intensive droplet-film flow mode with prevailing droplet mode. High permeability testifies to the energy efficiency of the use of such packing materials, and the development of an intensive droplet flow mode fits the requirements of evaporation cooling process of industrial recirculated water and ensures availability of mathematical modelling of the evaporation cooling process with developed algorithms and software [51, 60].

Apart from that, we would like to underscore the fact that many samples of the packing materials represented by the wastes from metal-working machines have significant elastic properties [54, 55] (they preserve their elastic properties within a wide range of volumetric deformations of the packing blocks) that enables current automated adjustment of various mass exchange apparatuses operation modes [54-56, 61-63], including evaporation cooling apparatuses for industrial recirculated water [64], thus, self-adaptation of the packing blocks in evaporation cooling apparatuses and shift to energy saving operation modes are available.

This work was supported by a grant from the President of the Russian Federation (MK-1287.2020.8) «Modelling of control processes in mass transfer environmental and petroleum processing equipment»

\section{References}

1. A. Dmitriev, I. Madyshev, O. Dmitrieva, Experimental Study of Hydraulic and Heat and Mass Transfer Parameters of Inclined-corrugated Contact Elements of Cooling Tower Sprinkler, Ecology and Industry of Russia, 24(1), pp. 4-8 (2020) 
2. I.N. Madyshev, A.I. Khafizova, O.S. Dmitrieva, The study of gas-liquid flow dynamics in the inclined-corrugated elements of cooling tower filler unit, E3S Web of Conf., 126, 00031 (2019)

3. I.N. Madyshev, A.V. Dmitriev, A.I. Khafizova, Estimation of Cooling Capacity of Reagent-Free Evaporative Cooling Tower, International Multi-Conference on Industrial Engineering and Modern Technologies (FarEastCon), IEEE Xplore, pp. 1-4 (2019)

4. A.V. Persidskiy, N.A. Merentsov, V.N. Lebedev, A.B. Golovanchikov, IOP Conf. Ser.: Earth and Environmental Science, 288, 012110 (2019)

5. I.N. Madyshev, O.S. Dmitrieva, A.V. Dmitriev, Efficiency of cooling the water droplets within Jet-Film unit of cooling tower filler , MATEC Web of Conf., 224, 02079 (2018)

6. N.A. Merentsov, V.N. Lebedev, A.B. Golovanchikov, V.A. Balashov, E.E. Nefed'Eva, IOP Conf. Ser: Earth and Environmental Science, 115, 012017 (2018)

7. I.N. Madyshev, O.S. Dmitrieva, A.V. Dmitriev, Development of New Types of Contact Devices for Heat-Mass Transfer Apparatuses, Used at Petrochemical Enterprises, Proceedings of the 5th International Conference on Industrial Engineering (ICIE 2019), Lecture Notes in Mechanical Engineering, pp. 95-101. (2019)

8. I.N. Madyshev, O.S. Dmitrieva, A.V. Dmitriev, MATEC Web of Conf., 194, 01036 (2018)

9. Sokol B.A., Chermyshov A.K., Baranov D.A., Mass-transfer column packed-type devices (Infokhim, Moscow, 2009).

10. Kagan A.M., Laptev A.G., Pushnov A.S., Farakhov M. I., Contact packings in industrial heat-and-mass transfer apparatuses (Otechestvo, Kazan, 2013).

11. I.N. Madyshev, O.S. Dmitrieva, A.V. Dmitriev, A.N. Nikolaev, Chem. and Pet. Eng., 52, 299 (2016)

12. N.A. Merentsov, V.N. Lebedev, A.V. Persidskiy, V.A. Balashov, IOP Conf. Ser.: Earth and Environmental Science, 288, 012106 (2019)

13. A.S. Sokolov, A.S. Pushnov, M.V. Shapovalov, Chem. and Pet. Eng., 53, 1 (2017)

14. O.S. Dmitrieva, A.V. Dmitriev, I.N. Madyshev, A.N. Nikolaev, Chem. and Pet. Eng., 53, 130 (2017)

15. A.K. Mitin, N.E. Nikolaikina, A.S. Pushnov, N.A. Zagustina, Chem. and Pet. Eng., 52, 47 (2016)

16. A.V. Dmitriev, O.S. Dmitrieva, I.N. Madyshev, Chem. and Pet. Eng., 53, 430 (2017)

17. M.G. Berengarten, R.I. Bogdanov, V.E. Voronina, Chem. and Pet. Eng., 47, 111 (2011)

18. A.V. Dmitriev, O.S. Dmitrieva, I.N. Madyshev, A.N. Nikolaev, Chem. and Pet. Eng., 53, 501 (2017)

19. A.A. Gorodilov, A.S. Pushnov, M.G. Berengarten, Chem. and Pet. Eng., 50, 84 (2014)

20. I.N. Madyshev, O.S. Dmitrieva, A.V. Dmitriev, A.N. Nikolaev, Chem. and Pet. Eng., 51, 383 (2015)

21. A.E. Ivanov, M.G. Berengarten, M.I. Klyushenkova, Chem. and Pet. Eng., 46, 433 (2010)

22. K.V. Chizh, A.S. Pushnov, M.G. Berengarten, Chem. and Pet. Eng., 50, 244 (2014)

23. N.S. Efimenko, I.A. Sabanaev, I.N. Madyshev, MATEC Web of Conf., 298, 00026 (2019)

24. M.V. Shilin, M.G. Berengarten, A.S. Pushnov, M.I. Klyushenkova, Chem. and Pet. Eng., 48, 608 (2013)

25. M.G. Berengarten, A.O. Nevelson, A.S. Pushnov, Chem. and Pet. Eng., 48, 723 (2013) 
26. I.N. Madyshev, O.S. Dmitrieva, A.V. Dmitriev, MATEC Web of Conf., 91, 01019 (2017)

27. A.M. Kagan, L.A. Yudina, A.S. Pushnov, Theor. Found. of Chem. Eng., 46, 165-171 (2012)

28. I.N. Madyshev, O.S. Dmitrieva, A.V. Dmitriev, MATEC Web of Conf., 141, 01023 (2017)

29. A.A. Gorodilov, M.G. Berengarten, A.S. Pushnov, Theor. Found. of Chem. Eng., 50, 325 (2016)

30. I.N. Madyshev, O.S. Dmitrieva, A.V. Dmitriev, MATEC Web of Conf., 141, 01012 (2017)

31. G.B. Dmitrieva, M.G. Berengarten, A.S. Pushnov, V.Y. Poplavskii, F. Marshik, Chem. and Pet. Eng., 42, 361 (2006)

32. A.V. Dmitriev, I.N. Madyshev, O.S. Dmitrieva, Engineering Method of Calculation for the Scrubber with Jet-Film Contact Devices, International Multi-Conference on Industrial Engineering and Modern Technologies (FarEastCon). IEEE Xplore, pp. 1-5 (2019)

33. A. Golovanchikov, N. Merentsov, Advances in Intelligent Systems and Computing, 983, 635 (2019)

34. A.B. Golovanchikov, N.A. Merentsov, M.V. Topilin, Journal of Phys.: Conf. Ser., 1278, 012023 (2019)

35. A.S. Pushnov, M.G. Berengarten, M.G. Lagutkin, A.S. Sokolov, A.I. Shustikov, Chem. and Pet. Eng., 44, 307 (2008)

36. I.N. Madyshev, O.S. Dmitrieva, A.V. Dmitriev, MATEC Web of Conf., 194, 01013 (2018)

37. A.A. Gorodilov, M.G. Berengarten, A.S. Pushnov, Theor. Found. of Chem. Eng., 50, 422 (2016)

38. A.S. Pushnov, M.G. Berengarten, A.M. Kagan, A.S. Ryabushenko, A.V. Stremyakov, Chem. and Pet. Eng., 43, 575 (2007)

39. K.B. Komissarov, A.V. Fil', V.A. Finochenko, Chem. and Pet. Eng., 53, 814 (2018)

40. G.V. Kuznetsov, D.V. Feoktistov, E.G. Orlova, S. Y. Misyura, V.S. Morozov, A.G. Islamova, Int. J. Heat Mass Transfer, 126, 161 (2018)

41. I.N. Madyshev, A.V. Dmitriev, Dang Suan Vin, IOP Conf. Ser.: Mater. Sci. and Eng., 709, 033025 (2020)

42. N.A. Merentsov, A.B. Golovanchikov, M.V. Topilin, A.V. Persidskiy, D.A. Tezikov, Journal of Phys.: Conf. Ser., 1399, 055028 (2019)

43. A. Dmitriev, I. Madyshev, O. Dmitrieva, Cleaning of Industrial Gases from Aerosol Particles in Apparatus with Jet-Film Interaction of Phases, Ecology and Industry of Russia, 22(6), pp.10-14 (2018)

44. K. Ponomarev, E. Orlova, D. Feoktistov, EPJ Web Conf., 110, 01060 (2016)

45. A.B. Golovanchikov, N.A. Merentsov, M.V. Topilin, A.V. Persidskiy, IOP Conf. Ser.: Earth and Environmental Science, 288, 012089 (2019)

46. V. Maksimov, T. Sharifulin, L. Zhidkova, K. Eloyan, EPJ Web Conf., 159, 00033 (2017)

47. M. Shilyaev, E. Khromova, A. Bogomolov, MATEC Web of Conf., 115, 08006 (2017)

48. A.E. Ivanov, M.G. Berengarten, M.I. Klyushenkova, Chem. and Pet. Eng., 45, 526 (2009)

49. O.S. Dmitrieva, A.V. Dmitriev, I.N. Madyshev, L.V. Kruglov, MATEC Web of Conf., 129, 06010 (2017) 
50. I.N. Madyshev, O.S. Dmitrieva, A.V. Dmitriev, Determination of Settling Efficiency of Solid Finely Dispersed Particles Within Devices with Rectangular Separators, Proceedings of the 5th International Conference on Industrial Engineering (ICIE 2019), Lecture Notes in Mechanical Engineering, v. II, pp. 79-84 (2019)

51. A.B. Golovanchikov, N.A. Merentsov, V.A. Balashov, Chem. and Pet. Eng., 48, 595 (2013)

52. N. Merentsov, A. Persidskiy, V. Lebedev, A. Golovanchikov, The use of industrial wastes from machine-building enterprises as packing materials for small-sized absorbers for gas emissions purification, MATEC Web of Conf., 298, 00031 (2019)

53. N.A. Merentsov, A.V. Persidskiy, V.N. Lebedev, Use of Wastes from Metalworking Machining for Packings in Contact Heat-and-Mass Exchange Devices, Proceedings of the 5th International Conference on Industrial Engineering (ICIE 2019), Lecture Notes in Mechanical Engineering, v. II, pp. 1443-1454 (2020)

54. N. Merentsov, A. Persidskiy, V. Lebedev, M. Topilin, A. Golovanchikov, Advances in Intelligent Systems and Computing, 983, 560 (2019)

55. N. Merentsov, A. Persidskiy, M. Topilin, Description of the process and packing materials for pulse liquid extraction, Materials Today: Proceedings, v. 19(5), pp. 19081912 (2019)

56. N. Merentsov, A. Persidskiy, M.Topilin, A. Golovanchikov, Sectional automatic adjustment of catalyst layers in gas and liquid phase reactors, MATEC Web of Conf., 298, 00030 (2019)

57. N.A. Merentsov, A.V. Persidskiy, M.V. Topilin, V.N. Lebedev, V.A. Balashov, A.B. Golovanchikov, Journal of Phys.: Conf. Ser., 1278, 012024 (2019)

58. A.B. Golovanchikov, V.A. Balashov, N.A. Merentsov, Chem. and Pet. Eng., 53, 10 (2017)

59. N.A. Merentsov, V.A. Balashov, D.Y. Bunin, V.N. Lebedev, A.V. Persidskiy, M.V. Topilin, MATEC Web of Conf., 243, 5 (2018)

60. N. Merentsov, A. Persidskiy, V. Lebedev, N. Prokhorenko, A. Golovanchikov, Advances in Intelligent Systems and Computing, 983, 547 (2019)

61. N. Merentsov, A. Persidskiy, V. Lebedev, Automatic parameter adjustment system for packing materials and control of flow modes in mass exchange columns, Materials Today: Proceedings, v. 19(5), pp. 1899-1903 (2019)

62. N. Merentsov, A. Persidskiy, V. Lebedev, A. Golovanchikov, Automatic Control of Operating Modes of Packed Apparatus for Selective Gas Emissions Cleaning, Ecology and Industry of Russia, 24(2), pp. 10-16 (2020)

63. N.A. Merentsov, A.V. Persidskiy, V.V. Groshev, V.A. Kozlovtsev, A.B. Golovanchikov, Journal of Phys.: Conf. Ser., 1399,044041 (2019)

64. N.A. Merentsov, V.N. Lebedev, A.V. Persidskiy, A.B. Golovanchikov, Journal of Phys.: Conf. Ser., 1515, 022004 (2020) 